\title{
New data on the palaeobiogeography of Early Jurassic marine reptiles: the Toarcian ichthyosaur fauna of the Vocontian Basin (SE France)
}

\author{
Valentin Fischer, Brussels, Myette Guiomar, Digne-les-Bains and Pascal Godefroit, Brussels
}

With 9 figures, 3 tables

\begin{abstract}
The Vocontian Basin (SE France) was formed along the northwestern border of Tethys during Mesozoic times. Mainly known for its rich ammonite fauna, this basin has also yielded several Lower Jurassic ichthyosaurs. The specimens discussed here were discovered in lower Toarcian limestone and marl successions in the vicinity of Digne-les-Bains, High-Provence Alps. The bestpreserved specimen is identified as Suevoleviathan sp., a rare taxon previously reported only in southern Germany. Along with this specimen, premaxillae and paddle elements of Eurhinosaurus sp. and probable Stenopterygiidae centra were found in neighbouring localities. These specimens were preserved thanks to the deposition of soft anoxic marls or calcarodetritic sediments, coeval with other anoxic shales in Europe (the Toarcian Oceanic Anoxic Event or T-OAE), which allows faunal comparisons between these basins. The localities from the Vocontian Basin are closer to the Tethys than any other sites where identifiable Toarcian ichthyosaurs have been found in Europe.

Nevertheless, the Vocontian ichthyosaur assemblage is strikingly similar to those in other basins across Europe. It suggests that Toarcian ichthyosaurs had a wide palaeobiogeographical distribution, reflecting their anatomical adaptations as highly mobile swimmers.
\end{abstract}

Key words: Ichthyosauria, Suevoleviathan, Palaeobiogeography, Toarcian, Vocontian Basin, southeastern France.

\section{Introduction}

Ichthyosaurs were a very successful lineage of Mesozoic marine reptiles, ranging from the Olenekian (SANDER 2000; MOTANi 2005) to the end of the Cenomanian (BARDET 1992; 1994). Early Jurassic ichthyosaurs are very abundant in Western Europe, especially in the Toarcian, where thousands of specimens are known (MCGOWAN 1991; GODEFROIT 1994) from a limited number of localities: the Holzmaden area in southern Germany, the Dudelange-Bascharage area in southern Belgium and Luxembourg, and the Whitby area on the Yorkshire coast of eastern England. Isolated and fragmentary Toarcian ichthyosaurs have been also reported from Switzerland (HUENE 1939; WEIDMANN 1981), central and northern Germany (MAISCH \& ANSORGE 2004), Normandy (MAZIN 1988; MAISCH \& MATZKE 2000), eastern France (PhARISAT 1993; PHARISAT et al. 1993), central France (ELMI \& RULLEAU 1991), southern France (LAMAUD 1979; SANDER \& BUCHER 1993) and the Iberian Peninsula (BARDET et al. 2008).

In this paper we describe the Toarcian ichthyosaur fauna from the Vocontian Basin, in southeastern France (fig. 1). This region is mostly known for its rich ammonite fauna (FLOQUET et al. 2003; 2007). Nevertheless, a dozen ichthyosaur specimens have been collected since 1960 (FLOQUET et al. 2007). This collection is housed at the Réserve Géologique Naturelle de Haute-Provence (RGHP), in Digneles-Bains, department of Alpes de Haute-Provence, France. The Vocontian Basin was closer to the Tethys than any other ichthyosaur-bearing locality in the European archipelago during the Toarcian 
(ARIAS \& WHATLEY 2005; ARIAS 2007; LÉONIDE et al. 2007; MAILliOT et al. 2009), and was separated by several hundreds of kilometres from the typical localities mentioned above. The aim of this paper is twofold: to describe the best-preserved specimens housed at the RGHP, and to compare the ichthyosaur assemblage of the Vocontian Basin (and the broader context of southern France) with that of other Western European localities.

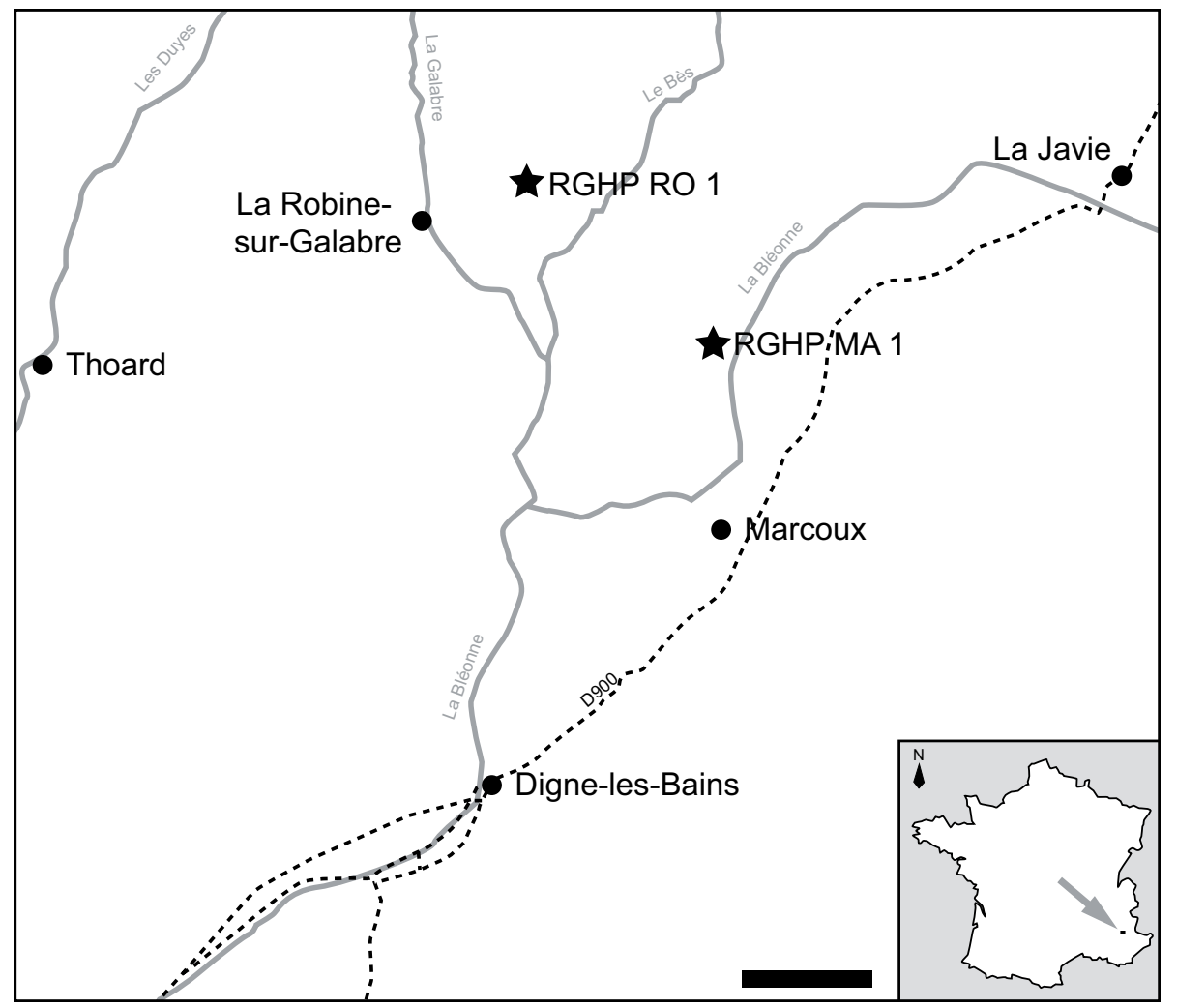

Figure 1: Map of the Digne-les-Bains area and position of the two most complete specimens. Dashed lines represent major roads and gray lines represent major rivers. Scale bar equals $2 \mathrm{~km}$.

Institutional abbreviations. RGHP: Réserve Géologique de Haute-Provence, Digne-lesBains, France.

\section{Geological and stratigraphic settings}

The Vocontian Basin or Vocontian Trough was a deep, highly subsident Mesozoic basin located at the northwestern border of the Tethys. It represents the deepest structural unit of the Dauphinois Basin, the Vercors carbonate platform representing its shallow part (WILPSHAAR et al. 1997). The Dauphinois Basin is one of the extensional basins created by the formation of the Liguro-Piemontan Ocean, starting in the Early Jurassic, the oceanization process of which ended during the Callovian (FLOQUET et al. 2003; DANELIAN et al. 2006). Subsequently, the Dauphinois Basin was subject to intense bloc tectonics, resulting in second order transgression-regression cycles (DE GRACIANSKY et al. 1993; FLOQUET et al. 2003). As demonstrated by FLOQUET et al. (2003), some parts of the Vocontian Basin were subject to extreme sediment starvation during the Toarcian: in the Digne-les-Bains area, where all the specimens described herein originate, only $10 \%$ of the whole stage is represented in the sedimentary record (see table 1). Three Toarcian lithological units cover an uppermost Pliensbachian hardground named "calcaires boudinés" consisting of tectonized limestones of the hawskerense horizon (hawskerense Subzone, spinatum Zone) (FLOQUET et al. 2003): the "marnes noires 
inférieures", consisting of a wedge of anoxic black marls of the strangewaysi and falciferum horizons (exaratum and falciferum Subzones, falciferum Zone, lower Toarcian), the "calcaires roux noduleux", consisting of reddish limestones rich in cephalopod remains that formed during the whole bifrons Subzone (bifrons Zone, middle Toarcian), and the "marnes noires supérieures", consisting of anoxic black marls of the mactra Subzone (aalensis Zone, uppermost Toarcian) (see fig. 2).

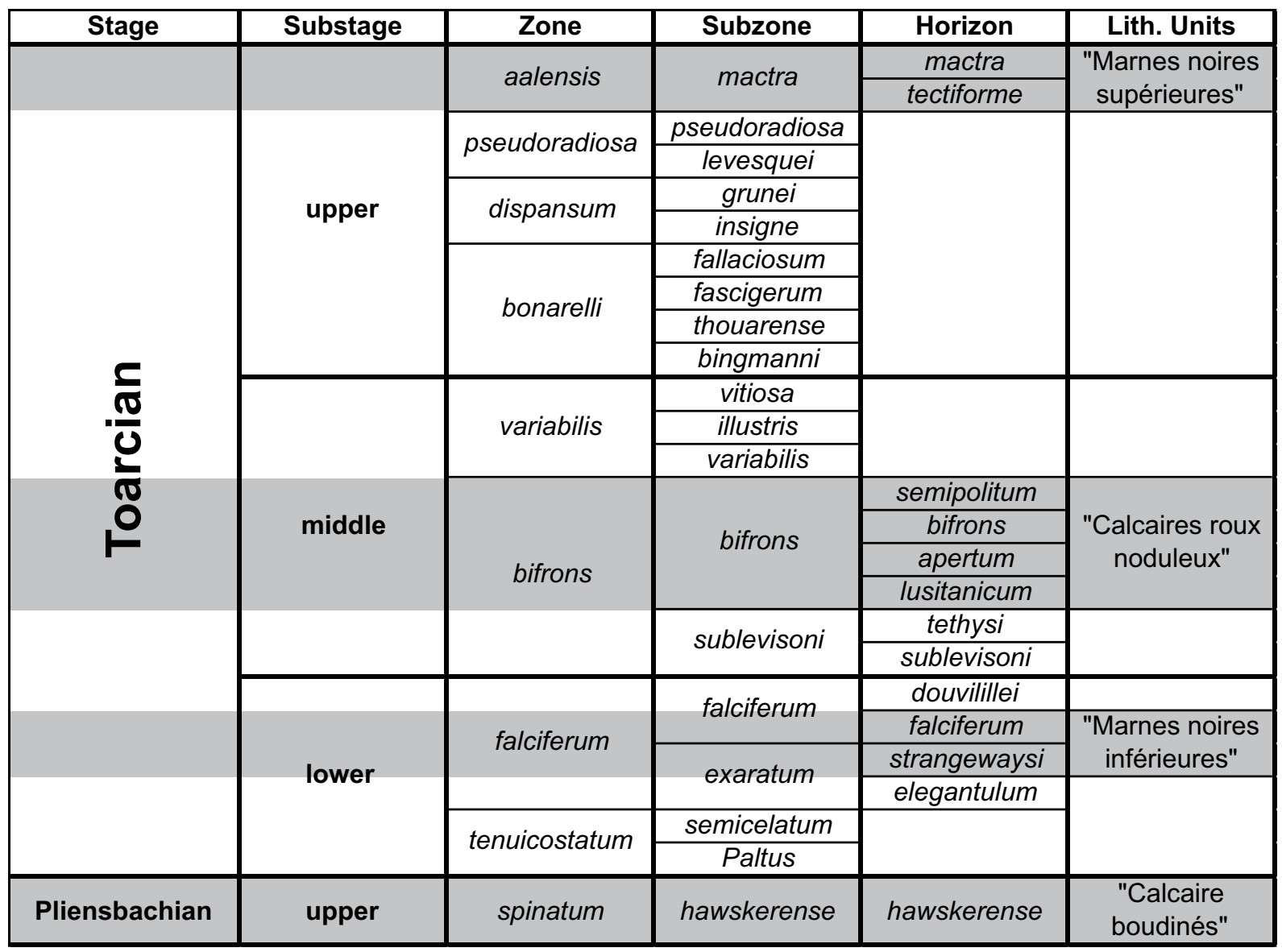

Table 1: Biostratigraphy of the lithological units in the La Robine and Marcoux areas. The sedimentary record represents only about $10 \%$ of whole Toarcian (FLOQUET et al. 2003). 


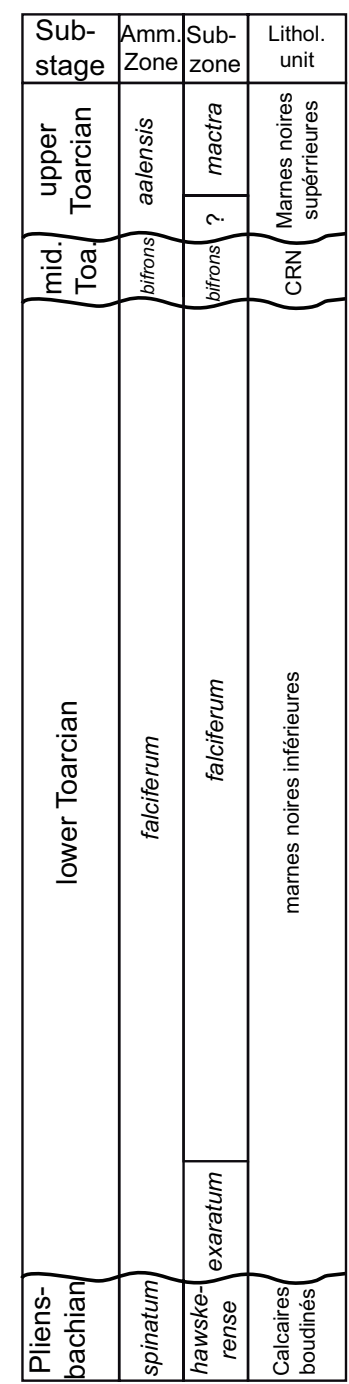

Marcoux section

La Robine section

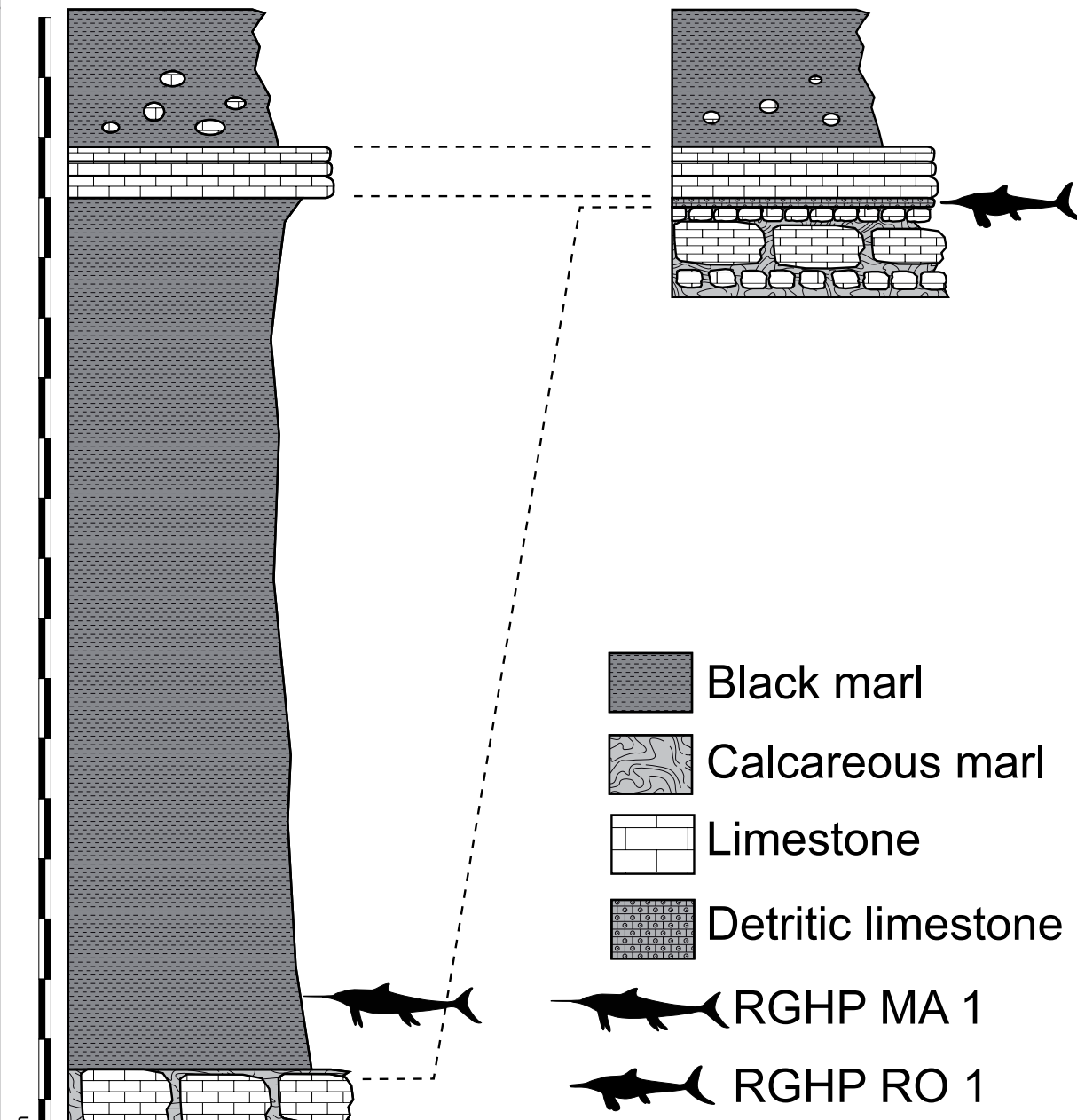

Figure 2: Stratigraphic logs of the Marcoux and La Robine sections and their correlation, highlighting the numerous sedimentary gaps present in this part of the Vocontian Basin in the Toarcian. CRN stands for "Calcaires roux noduleux".

\section{Systematic palaeontology}

Order Ichthyosauria DE BLAINVILLE, 1835

Neoichthyosauria SANDER, 2000

Family Suevoleviathanidae MAISCH \& MATZKE, 2000

Genus Suevoleviathan MAISCH, 1998a

Ty p e species. - Suevoleviathan disinteger (HUENE, 1926).

Additional species. - Suevoleviathan integer (BRONN, 1844).

D i a g n o s i s. - See MAISCH \& MATZKE (2000) and MAISCH (2001)

Ge ographical distribution. - Holzmaden (Baden-Württenberg, Germany), La Robine-sur-

Galabre (Department of Alpes de Haute Provence, France).

Stratigraphic distribution. - Lower Toarcian (Lower Jurassic).

\section{Suevoleviathan $\mathrm{sp.}$}

Figs. 3-7 
Referred specimen.- RGHP RO 1, a sub-complete skeleton discovered in the early 1960's by cartographers during field surveys. The dorsal side of the specimen has been prepared, but it is conserved in situ, under a Plexiglas shelter.

L o c a 1 it y . - Northeast side of La Robine synclinal, La Robine-sur-Galabre, southeastern France. Geographic coordinates: $44^{\circ} 10^{\prime} 29^{\prime \prime} \mathrm{N}-6^{\circ} 14^{\prime} 18^{\prime \prime} \mathrm{E}$.

Horizon. - There has been much debate about the correct age of RGHP RO 1, because of its position within a sedimentary gap, between the uppermost Pliensbachian "calcaire boudinés" and the middle Toarcian "calcaires roux noduleux" (CRN) (fig. 2). The lower Toarcian "marnes noires inférieures" are absent here, but the specimen is embedded in a light gray detritic limestone. HACCARD et al. (1989) considered the ichthyosaur to be embedded in the "calcaires boudinés" as well as in the "calcaires roux noduleux". However, the 6 my gap between these two lithological units (FLOQUET et al. 2003) makes this highly unlikely. More recently, FLOQUET et al. (2003) placed RGHP RO 1 within the strangewaysi horizon (serpentinum Zone, exaratum Subzone), only because other nearby ichthyosaurs from the Vocontian Basin (e.g. RGHP MA 1, see below) come from that interval. New field observations confirm the post-Pliensbachian and pre-middle Toarcian age of RGHP RO 1. The roof of the "calcaires boudinés" is a hardground that was densely perforated by hard substrate communities (FLOQUET et al. 2003; pers. obs.). It is commonly accepted that boring organisms pass through most of the encountered lithologies, clasts and fossils (TAYLOR \& WILSON 2003). Although the "calcaires boudinés" exhibit numerous boreholes around the specimen, none is found on the specimen itself, indicating that it was deposited after the lithification and boring of the late Pliensbachian "calcaires boudinés". The light gray detritic limestone embedding the specimen does not correspond to the middle Toarcian CRN, because the base of this formation contains an enormous amount of compressed ammonite and nautiloid shells (FLOQUET et al. 2003; pers. obs.), whereas none are found in association with the ichthyosaur. Because sedimentation events in this part of the Vocontian Basin were extremely rare during the Toarcian (see above), this light gray detritic limestone probably was deposited during the only sedimentation event between late Pliensbachian and middle Toarcian: the sedimentation of the "marnes noires inférieures", during the middle part of falciferum Zone (strangewaysi and falciferum Horizons, see fig. 2 and table 1).

De s cription. - RGHP RO 1 is a sub-complete, $3 \mathrm{~m}$ long ichthyosaur lacking most of the tail. The skull, one tooth, the anterior dorsal region, parts of the pectoral girdle, the right forefin, parts of the right (?) hindfin, and fifteen anterior caudal centra are preserved (fig. 3, fig. 4). The skull lies on its ventral face, and the rest of the body lies on its left flank. The hindfin is oriented upside-down and back-to-front. Being embedded in limestone, the specimen kept a certain three-dimensionality. Some parts have been eroded away, weathered or partially destroyed during mechanical preparation, i.e. the skull, the proximal part of the humerus, the medial part of the right coracoid and several phalanges.

Note. Access to the specimen is very limited because it is preserved in situ under a Plexiglas shelter. All interpretations have been made on the original specimen, but some figures and drawings are based on a cast for clarity and convenience. This cast is exhibited in the "Musée promenade" of RGHP, in Digne-les-Bains. The cast is however badly painted; consequently, the bone outlines and the cast painting do not perfectly match in some figures. 


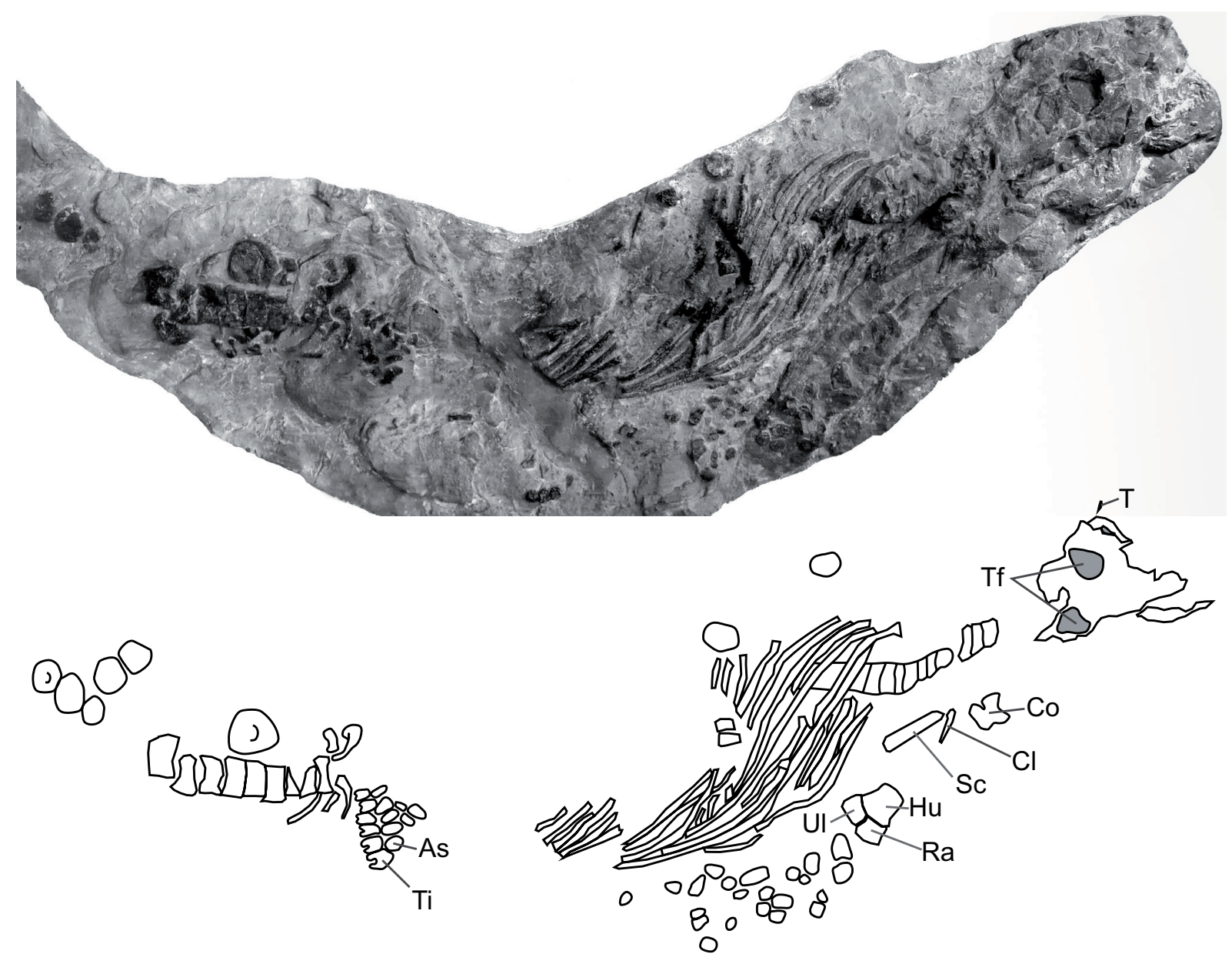

Figure 3: Suevoleviathan sp. (RGHP RO 1), photograph and drawing. As: astragalus, Cl: clavicle, Co: coracoid, Dg: dental groove, Fpm: fossa praemaxillaris, Hu: humerus, $\mathrm{Ph}$ : phalanges, Pmx: premaxilla, Ra: radius, $\mathrm{Rb}$ : rib(s), Sc: scapula, T: tooth, Tf: temporal fenestrae, Ti: tibia, Ul: ulna. The temporal fossae are large, the coracoid is notched and hexagonal in shape and the fins are markedly different: the forefin fans out distally and is composed of rounded, unnotched elements, whereas the hindfin is narrow and composed of polygonal, tightly interlocking elements. The elements of the first digit of the hindfin are all notched. Scale bar equals $50 \mathrm{~cm}$.

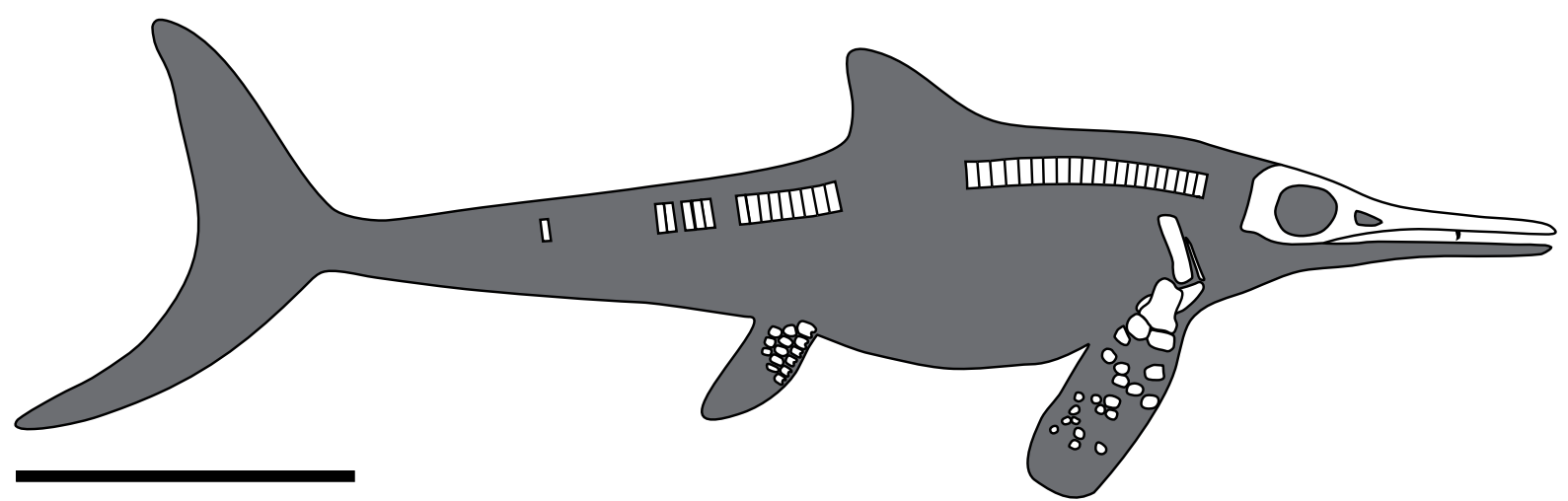

Figure 4: Suevoleviathan sp. (RGHP RO 1), reconstruction based on drawings from HUENE (1926) and MAISCH (1998b). Scale bar equals $1 \mathrm{~m}$. 
Skull. The skull is crushed and weathered. Consequently, all sutures have been worn away, making the identification of individual elements difficult. The preserved part of the skull extends anteriorly up to $20 \mathrm{~cm}$ beyond the anterior margin of the nasals. The postnarial region is presumably complete, but not identifiable. The total preserved length of the skull is $760 \mathrm{~mm}$. Of the rostrum, only the posterior part of the right premaxilla is discernible. It is crushed, and lost contact with the nasal. Only the two nasals can be recognized. The two temporal fenestrae are fairly well preserved. They are elliptical and relatively large. The left prefrontal, the left postfrontal, the anteroventral part of the left orbit, and the left jugal are also present.

Tooth. One complete tooth has been discovered. It lies outside the skull, close to the left jugal. The tooth is $39 \mathrm{~mm}$ high. It is conical, slightly recurved but badly preserved, lacking the enamel. The crown is high $(15 \mathrm{~mm})$ and seems fairly acute. The root is not bulbous.

Axial skeleton. About twenty-nine centra and twenty ribs are preserved and prepared. The centra from the posterior thoracic and anterior caudal regions are approximately $9 \mathrm{~cm}$ high and about $3.5 \mathrm{~cm}$ long. An anterior series of about fourteen centra from the anterior dorsal region is covered by about eighteen short and flattened ribs. A second series of fifteen centra probably originates from the anterior caudal region, because of their relative position, and their high aspect ratio.

Pectoral girdle. The right part of the pectoral girdle is preserved (fig. 5). The scapula is long, straight and robust. Its proximal end is missing. The right clavicle is also incomplete. It is long, narrow, and apparently completely straight. The coracoid is the most complete bone of the girdle. It exposes its flat dorsal surface. It has a hexagonal outline, and a deep but narrow anterior notch. Its lateral (posterior to the humeral facet) and posterior margins are concave, which is unusual and has sometimes been considered as pathological in ichthyosaurs (MAISCH pers. comm. 2010).

Consequently, the articular facets for the scapula and the humerus appear set off from the medial part of the coracoid. The interclavicle is missing. 

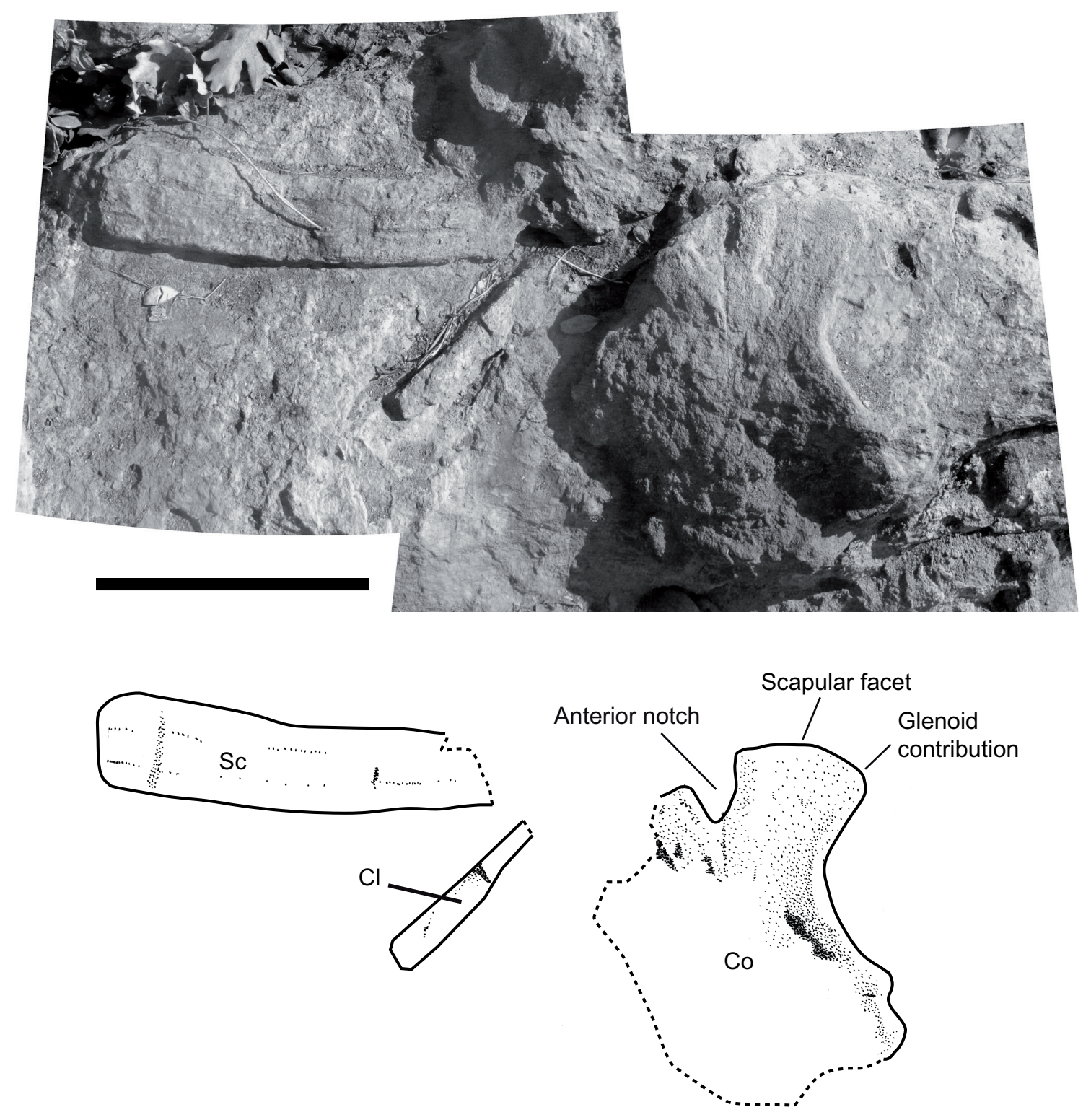

Figure 5: Suevoleviathan sp. (RGHP RO 1), photograph and drawing of the pectoral girdle. The right coracoid is seen in dorsal view. It is hexagonal and bears a well-marked anterior notch. The posterior margin is concave, which is unusual. The blade of the scapula is straight. See fig. 3 caption for anatomical abbreviations. Scale equals $100 \mathrm{~mm}$.

Forefin. The right forefin is preserved. The humerus, radius, and ulna are articulated, whereas the remaining twenty-four paddle elements are slightly displaced (fig. 6). The humerus lacks its proximal and posterodistal ends. It is a stout, unconstricted bone that slightly expands at its distal end. Its distal surface bears two facets of equal size, one for the radius and one for the ulna. The radius and the ulna are of the same size, polygonal and articulate which each other along a straight facet. The central part of the ulna is missing (fig. 6). Unlike the zeugopodium, carpals and phalanges are rounded or oval in shape, indicating that they were not in close contact in vivo. All paddle elements are unnotched. Even though some phalanges are missing and others have been slightly displaced, the forefin apparently fans out distally. 


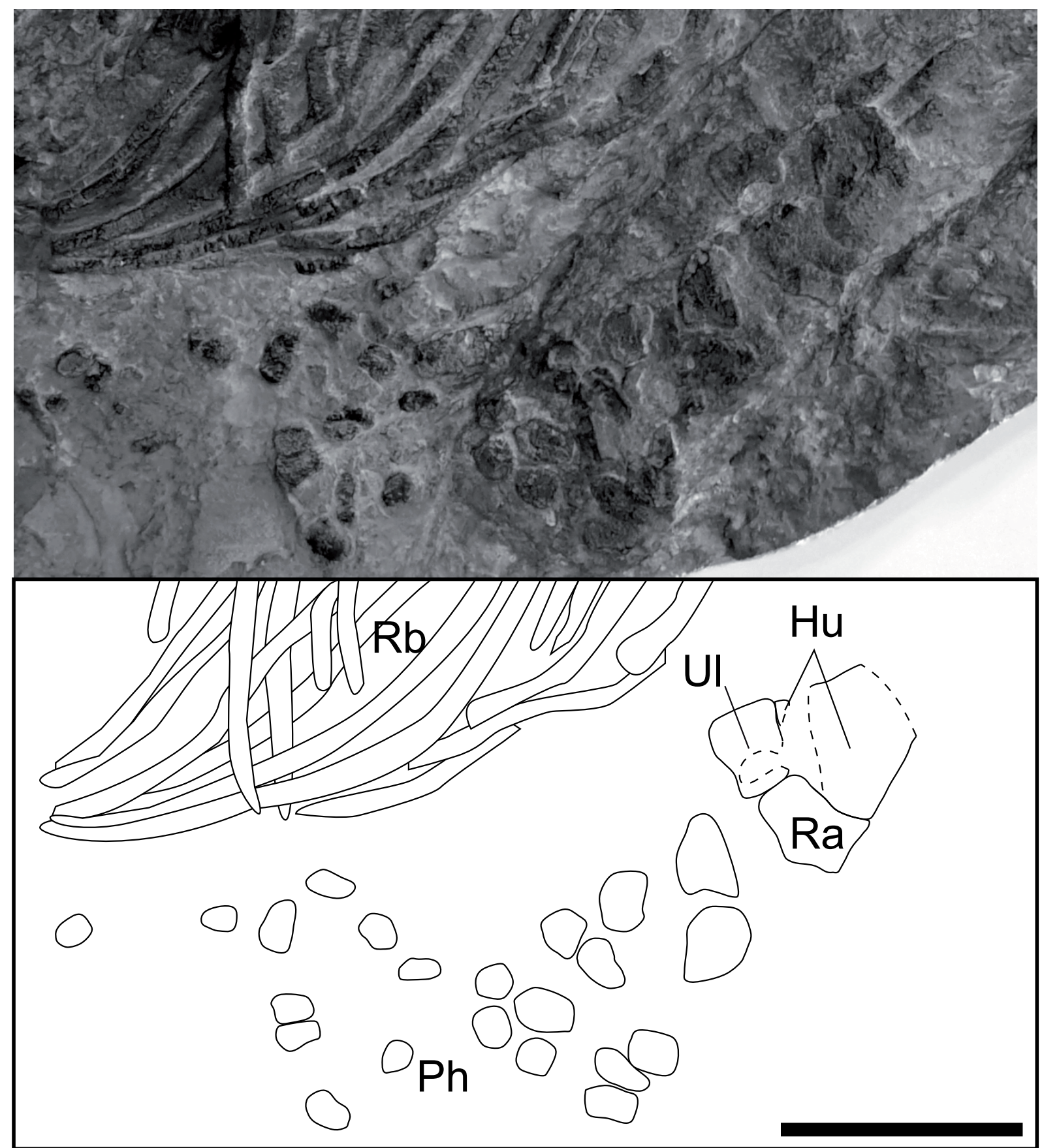

Figure 6: Suevoleviathan sp. (RGHP RO 1), photograph and drawing of the right forefin in dorsal view. See fig. 3 caption for anatomical abbreviations and taxonomic features. Scale bar equals $20 \mathrm{~mm}$. 

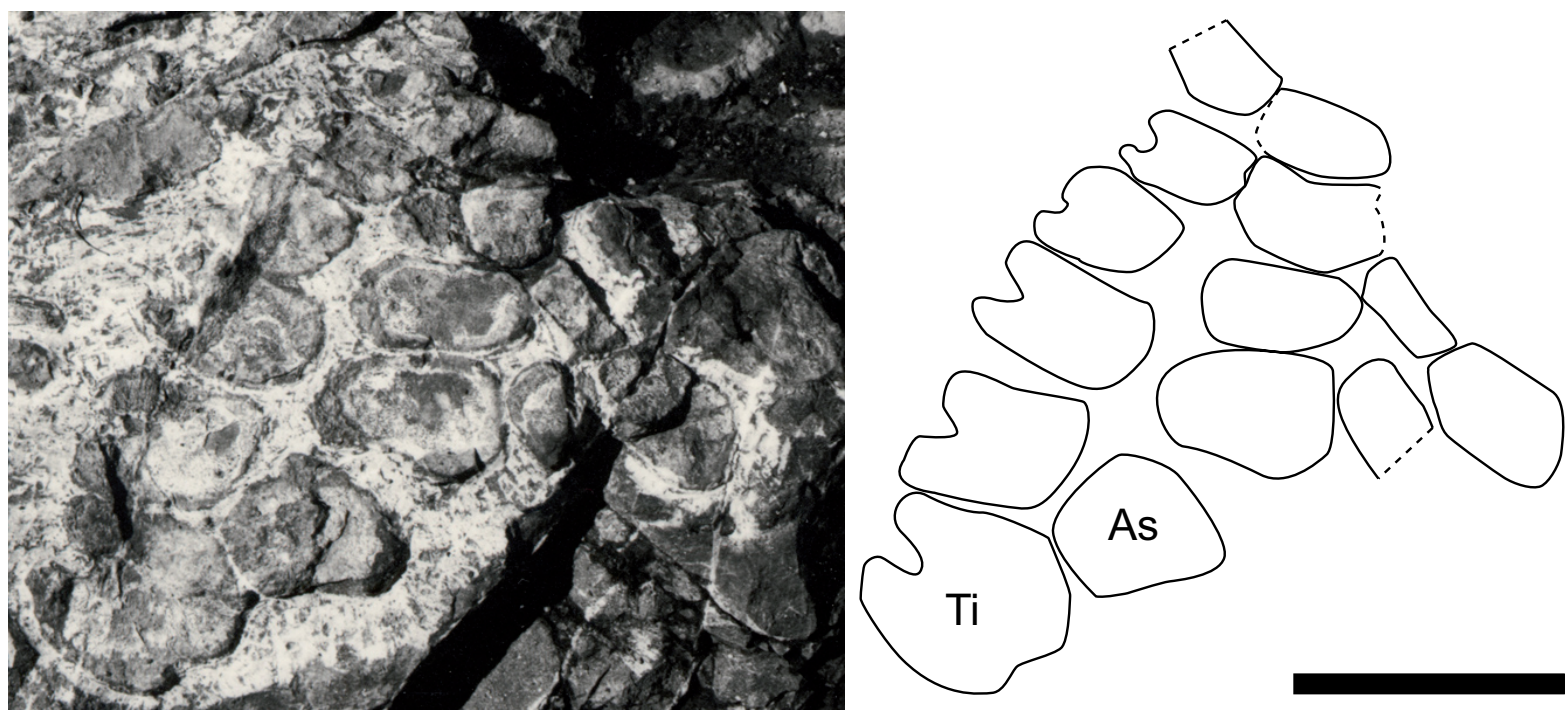

Figure 7: Suevoleviathan sp. (RGHP RO 1), photograph and drawing of the ?right hindfin in dorsal view. See fig. 3 caption for anatomical abbreviations and taxonomic features. Scale bar equals $100 \mathrm{~mm}$.

Hindfin. The median part of the ?right hindfin is preserved. It is composed of fourteen subpolygonal elements articulated in an alternating fashion. The tibia is hexagonal in shape and is deeply notched, as are all the elements of the first digit (fig. 7). The astragalus is pentagonal in shape. The first digit is the most complete, being represented by a continuous series of five elements articulated with the tibia. The second digit is represented by a continuous series of four elements arising from the astragalus. A third digit is present, but its elements are slightly displaced. The numerous phalanges, their large size, and their polygonal shape at the distal end of the preserved part suggest that the hindfin was relatively large, probably approaching the size of the forefin: the series of five elements of the first digit and the tibia measure about $230 \mathrm{~mm}$, which is nearly half the size of the forefin $(\approx 500 \mathrm{~mm}$ ). Considering the missing femur and distal phalanges, the paired fin ratio (size of the forefin/size of the hindfin) was considerably less than 2 in RGHP RO 1, unlike in Ichthyosauroidea (a superfamily defined by MCGOWAN \& MOTANI (2003) as the last common ancestor of Stenopterygius quadriscissus, Ichthyosaurus communis, and Ophthalmosaurus icenicus and all its descendants).

Id entification. - Before identifying the specimen, it is important to assess its osteological maturity, because previous studies (JOHNSON 1977; GODEFROIT 1994; MCGOWAN 1994b; MAISCH 2008) showed that a great part of supposed interspecific differences between Liassic ichthyosaurs could be attributed to ontogenetic variation. Out of the four size-independent criteria proposed by JOHNSON (1977) to determine the relative age of ichthyosaurs, two can be used in RGHP RO 1. It is worthwhile to mention that these criteria were developed for Stenopterygius, but MCGOWAN (1994b) applied them successfully to Temnodontosaurus. Given the phylogenetic position of Suevoleviathan, being either the sister taxon (MOTANI 1999; MCGOWAN \& MOTANI 2003) or in an intermediate position between the aforementioned genera (MAISCH \& MATZKE 2000; SANDER 2000), these criteria are considered meaningful for RGHP RO 1. Observed criteria of maturity are the full closure of the radius-ulna contact zone, and the deep notches on the elements of the first digit of the hindfin. RGHP RO 1 exhibits the following combination of characters: a moderately large size ( $>3 \mathrm{~m})$; large temporal fossa; medium-sized, conical teeth; a hexagonal coracoid with a deep anterior notch; a straight scapula; a robust, non-constricted humerus; rounded, unnotched phalanges in the forefin; a forefin fanning out distally; notched, subpolygonal phalanges in the hindfin; and unreduced hindfins (paired fin ratio $<2$ ). This combination of characters is found in a single genus, Suevoleviathan 
(MAISCH 1998b). The remarkable morphological difference between the fore- and hindfins (forefin composed of widely spaced rounded phalanges fanning out distally, and tridactyle hindfin composed of more closely packed subpolygonal phalanges) is an autapomorphy of this genus (MCGOWAN 1979; MAISCH 1998b; MOTANI 1999; MAISCH \& MATZKE 2000). Moreover, the lack of an interclavicle has also been described in Suevoleviathan (MAISCH 1998b), although this is negative evidence. According to MAISCH (1998b; 2001), two species can be referred to the genus Suevoleviathan: Leptopterygius disinteger HUENE, 1926, and Ichthyosaurus integer BRONN, 1844, mainly differing in cranial and coracoid morphology. The coracoid of Suevoleviathan integer is described as rounder than that of $S$. disinteger, and lacks the anterior notch (LYDEKKER 1888; MAISCH 2001). However, the coracoid of $S$. disinteger lacks the posterior emargination that is found in RGPH RO 1. Consequently, that specimen is referred to Suevoleviathan sp.

Family Leptonectidae MAISCH, 1998b

Genus Eurhinosaurus ABEL, 1909

Ty p e species.-Eurhinosaurus longirostris (MANTELL, 1851)

Di agn os is. - See MCGowan \& MOTANi (2003).

Ge ographical distribution. - Whitby (England); Holzmaden and vicinity (Baden-

Württtenberg, Germany); Schandelah (near Braunschweig, Germany; MAISCH pers. comm. 2010); Dudelange (Grand-Duché de Luxembourg); Pic Saint-Loup, Noirefontaine and Marcoux (France);

Staffelegg (Switzerland; MAISCH pers. comm. 2010).

Stratigraphic distribution. - Lower Toarcian (Lower Jurassic).

\section{Eurhinosaurus sp.}

Fig. 8

Referred specimen.- RGHP MA 1, a rostrum, a vertebral centrum and paddle elements from the lower Toarcian of Marcoux.

L o c a lity. - Southern flank of the Minjau ravine, Marcoux, Department of Alpes de Haute Provence, southeastern France. Geographic coordinates: 44 9'6.04"N - 6 $166^{\prime} 35.38^{\prime \prime} \mathrm{E}$ H o r i zo n. - falciferum Zone, exaratum Subzone, strangewaysi Horizon (fig. 2) (FLOQUET et al. 2003).

De s cription. - RGHP MA 1 is an incomplete ichthyosaur including an $86 \mathrm{~cm}$-long rostrum, forty-one teeth, thirty-two paddle elements and one centrum. The remains were found together with a large piece of wood.

Skull. The skull of RGPH MA 1 is represented by the anterior part of the premaxillae, articulated and preserved over a length of $86 \mathrm{~cm}$. The rostrum is crushed and laterally compressed, and the teeth are expelled from their dental grooves. The anteriormost part of the rostrum is strongly weathered. The premaxilla is a long, slender bone the thickness (dorsoventral height) of which ranges from 3 to $5 \mathrm{~cm}$. A well-marked but shallow lateral groove (fossa praemaxillaris) is present along either side of the rostrum along its whole preserved length. It is located approximately $2 \mathrm{~cm}$ above the dental groove. The dental grooves are narrow, straight and continuous. The lingual wall of the dental grooves is bulbous in cross-section (thin base, thick ventral end, see fig. 8). 


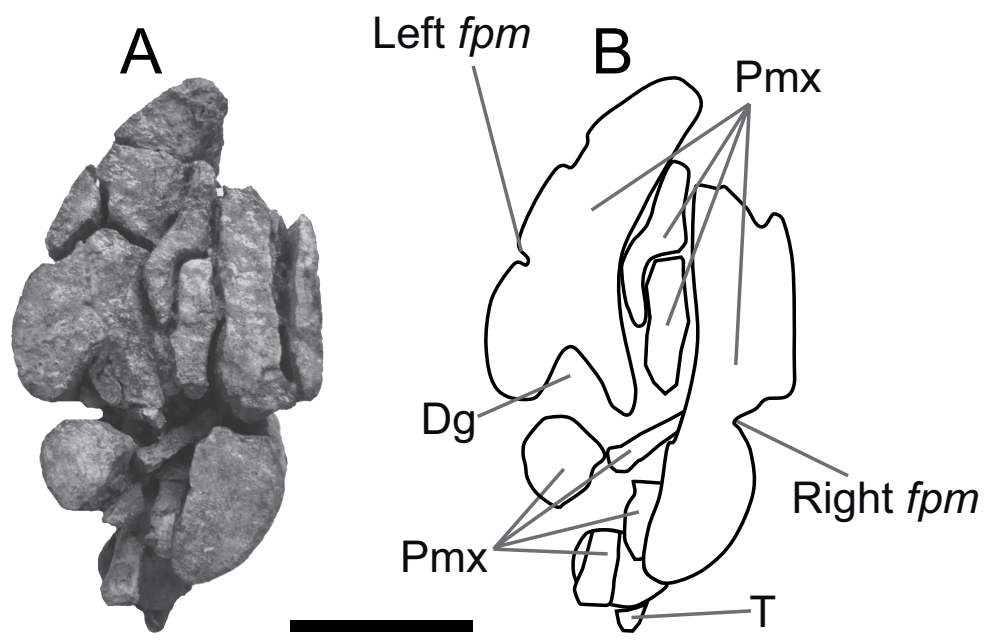

Figure 8: Eurhinosaurus sp. (RGHP MA 1), photograph (A) and drawing (B) of the proximal-most cross-section of the rostrum. The rostrum is slender and very elongated and the teeth are delicate, sharply pointed and the enamel is smooth. See fig. 3 caption for anatomical abbreviations. Scale bar equals $20 \mathrm{~mm}$.

Teeth. Forty-one teeth are preserved. Their height ranges from 11 to $26 \mathrm{~mm}$. The crown is slightly recurved, very elongate and narrow, ending in a very acute but slightly rounded tip. The crown is usually smooth, but some teeth are ornamented with horizontal, circular, and delicate striations in the middle of the crown. The crown is circular in cross-section. The root is ornamented by deep longitudinal ridges and is frequently bulbous.

Axial skeleton. A single, $8.7 \mathrm{~cm}$ transversely wide centrum is preserved. It is strongly weathered to a point where none of the apophyses is visible. Ten rib fragments are also preserved. The cross-section is rounded, and no proximal head is preserved.

Appendicular skeleton. Thirty-two paddle elements are preserved. Because most of them were not articulated, it is impossible to known from which $\operatorname{limb}(\mathrm{s})$ they originate. Two of these bones, with straight and rugose articular facets, are interpreted as elements from the zeugopodium or the basipodium. The biggest one is deeply notched. The remaining thirty elements are elliptical or circular, slightly biconcave and thin. They range from 1 to $6 \mathrm{~cm}$ wide.

Id entification. - Despite its incompleteness, RGHP MA 1 exhibits two important features: a long and slender rostrum and small, delicate, acute teeth, characteristic for the Lower Jurassic family Leptonectidae (MCGOWAN \& MOTANI 2003). Within this family, comprising Leptonectes (RhaetianPliensbachian) (MCGOWAN \& MILNER 1999; MAISCH \& REISDORF 2006), Excalibosaurus (Sinemurian) (MCGOWAN 1986; 1989a; 1989b; 2003) and Eurhinosaurus (Toarcian) (MAISCH \& MATZKE 2000; MCGOWAN 2003; MCGOWAN \& MOTANI 2003), the extreme slenderness of the rostrum, the smooth crowns with horizontal ridges, the relatively large size (centrum $87 \mathrm{~mm}$ wide) and the numerous rounded phalanges are typical for Eurhinosaurus (MCGOWAN 1994a; 2003).

Consequently, RGPH MA 1 is referred to the genus Eurhinosaurus. That genus is currently monotypic but the preliminary results of an ongoing revision of the genus indicate the presence of at least two different species (MAISCH pers. comm. 2010). Consequently, RGHP MA 1 is referred to Eurhinosaurus sp.

Thunnosauria MOTANI, 1999

Thunnosauria indet. aff. Stenopterygiidae 
Referred specimen.- RGHP RO 0a, RGHP RO 2, RGHP RO 9, centra from La Robine, and RGHP MA 2, centrum from Marcoux.

Localities and horizons.- RGHP RO Oa. La Robine-sur-Galabre, southeastern France.

Geographic coordinates: unknown. Toarcian.

RGHP RO 2. Eastern side of the La Robine lobe. Geographic coordinates: $44^{\circ} 10^{\prime} 15.49^{\prime \prime} \mathrm{N}-$ $6^{\circ} 14 ' 28.17 "$ "E. Lower Toarcian.

RGHP RO 9. Peylan locality, southwestern side of the La Robine lobe. Geographic coordinates: $44^{\circ} 10^{\prime} 15.49^{\prime \prime} \mathrm{N}-6^{\circ} 14^{\prime} 28.17^{\prime \prime}$. Lower black marls: strangewaysi to falciferum Horizons, exaratum and falciferum Subzones, falciferum Zone, lower Toarcian.

RGHP MA 2. Clos du Barrel ravine, Marcoux locality, southeastern France. Geographic coordinates: $44^{\circ} 8^{\prime} 55.22^{\prime \prime} \mathrm{N}-6^{\circ} 16^{\prime} 25.99^{\prime \prime} \mathrm{E}$. One meter above the base of the lower black marls: strangewaysi Horizon, exaratum Subzone, falciferum Zone, lower Toarcian.

De s cription. - RGHP RO Oa. A $35 \mathrm{~mm}$-wide centrum found by a private collector. The lateroventral orientation of the diapophyses and parapophyses indicates it originates from the posterior thoracic region.

RGHP RO 2. A discontinuous series of nine centra found in close association. They are small (about $42 \mathrm{~mm}$ in diameter, see table 2), strongly amphicœlous, and originate from various parts of the vertebral column: four anterior thoracic centra (parapophysis in lateral position, diapophysis in laterodorsal position), one posterior thoracic centrum (parapophysis and diapophysis and in lateroventral position), two anterior caudal centra (single apophysis in ventrolateral position) can be recognized. The remaining centra are incomplete.

RGHP RO 9. A deeply amphicœlous centrum $33.5 \mathrm{~mm}$ wide. The diapophyses are located lateroventrally and the parapophyses are located nearly ventrally. Diapophyses and parapophyses are close to each other. This indicates a centrum from the posterior thoracic region, probably close to the sacral region.

RGHP MA 2. A 39 mm-wide weakly amphicœlous centrum from the posterior thoracic region.

\begin{tabular}{cccc} 
Specimen & Width & Height & Region \\
\hline RGHP RO 0a & 35.0 & 33.0 & post. do. \\
& 39.8 & 37.4 & ant. do. \\
& 42.2 & 40.5 & ant. do. \\
RGHP RO 2 & 47.5 & 43.4 & ant. do. \\
& 44.3 & 47.4 & ant. ca. \\
& 46.2 & 45.5 & ant. ca. \\
RGHP RO 9 & 33.5 & 33.0 & post. do. \\
RGHP MA 2 & 39.8 & 40.6 & post. do.
\end{tabular}

Table 2: Thunnosauria indet. aff. Stenopterygiidae, width and height of the most complete centra from the La Robine and Marcoux localities. Ant.: anterior, ca.: caudal, do.: dorsal, post.: posterior. 
Id entification. - Among the abundant Toarcian material of the RGHP locality, mainly consisting of isolated ichthyosaur centra, RGHP RO 0a, RGHP RO 2, RGHP RO 9 and RGHP MA 2 are posterior thoracic centra with biccipital rib attachment. A biccipital rib attachment in the posterior thoracic region characterizes the clade Thunnosauria, including Ichthyosaurus, Stenopterygiidae (Stenopterygius, Hauffiopteryx) and post-Liassic ichthyosaurs (MAISCH \& MATZKE 2000: character 53). By Toarcian times, Thunnosauria were only represented by the Stenopterygiidae (MCGowAN \& MOTANI 2003; MAISCH 2008). The relatively small size of these centra supports their identification as Thunnosauria indet. aff. Stenopterygiidae.

\section{Discussion}

\subsection{The ichthyosaur assemblage from the Vocontian Basin and southern France}

By early Toarcian times, the Vocontian Basin was inhabited by a diverse ichthyosaur fauna with the co-occurrence of Suevoleviathan sp., Eurhinosaurus sp. and probable Stenopterygiidae. According to MASSARE's (1988) and BUCHHOLTZ's (2001) analyses of ichthyosaur locomotion, Suevoleviathan can be probably regarded as an ambush predator, relying on its wide forefins, extremely long caudal fin and narrow, flexible body to quickly gain speed. MASSARE (1987) also studied the dentition of Suevoleviathan disinteger, concluding it was probably suited to smash preys with light external armour. On the other hand, Stenopterygiidae are regarded as smaller, stiff, and fast swimmers (MASSARE 1988; GODEFROIT 1996; BUCHHOLTZ 2001; LINGHAM-SOLIAR \& PlODOWSKI 2007) with a dentition composed of small piercing teeth to impale small and probably fast preys (MASSARE 1987; 1988; pers. obs.). The ecology of Eurhinosaurus is more controversial. Its postcranial morphology is intermediate between those of sustained fast swimmers and slower, more flexible predators (BUCHHOLTZ 2001). The extreme overbite of Eurhinosaurus (more than 60\%; MCGOWAN \& MOTANI 2003) also led to many interpretations: MCGOWAN (1979) proposed a predatory strategy close to that of the swordfish (Xiphias), using the extremely elongated, densely toothed premaxillae as a weapon to wound small soft prey. The weakness of this theory is that unlike the swordfish, the teeth of Eurhinosaurus are set mostly vertically in the jaw (pers. obs.; MAISCH pers. comm. 2010). This implies efficient head movement in the vertical plane, which was probably limited in ichthyosaurs by the interlocking neural arches in the cervical region, and the fused atlas-axis complex. RIESS (1986) interpreted the rostrum of Eurhinosaurus as a sensory organ to scan the sea bottom, like the tooth of the extant narwhal (Monodon monoceros) because of the presence of a well-marked fossa praemaxillaris. However, well-marked and sometimes complex fossae praemaxillaris are present in several ichthyosaurs, such as Suevoleviathan (MAISCH 1998b), Ichthyosaurus intermedius (MAISCH 1997), Aegirosaurus (BARDET \& FERNÁNDEZ 2000), Platypterygius (MCGOWAN \& MOTANI 2003; KEAR 2005) and Brachypterygius (MCGOWAN 1976), which are not considered to have been bottom feeders (MASSARE 1987). Nevertheless, it is interesting to note that if Eurhinosaurus was ecologically similar to the narwhal, then a great part of the places where that uncommon genus has been discovered are thanatocenoses, because these were anoxic marls devoid of benthic or semi-benthic life (RÖHL et al. 2001; FlOQUET et al. 2003; SCHMID-RÖHL \& RÖHL 2003; MAILliOT et al. 2009), but Holzmaden specimens are complete and do not show any sign of post-mortem transport. According to MASSARE's criteria $(1987$; 1997), Eurhinosaurus belongs to the "Pierce I" predatory guild, whose dietary habits are composed of very small and very soft, delicate prey, such as small fishes and squids. This indicates that Toarcian ichthyosaurs from the Vocontian Basin were diversified, using a wide range of predatory strategies and hunting different prey items, allowing efficient niche partitioning. It is worthwhile to mention that despite evident biases concerning the number of specimens, we have not found any plesiosaur fossil in the Toarcian material from the Vocontian Basin housed at the RGHP, while two very fragmentary crocodile specimens, consisting of isolated vertebrae (RGHP RO 0c) and a partial 
rostrum (RGHP EN 1b), have been identified in the Lower Toarcian marls of La Robine and Entrage, compared to a total of at least twelve ichthyosaurs. This frequency is similar to that of the Holzmaden fauna (Sander, pers. comm. 2010).

Toarcian ichthyosaurs have been discovered in southern France outside of the Vocontian Basin as well (see also review in SANDER \& BUCHER 1993). LAMAUD (1979) reported two specimens of Eurhinosaurus longirostris from the middle part of the lower Toarcian black marls of Pic Saint-Loup, $20 \mathrm{~km}$ north of Montpellier. The possible presence of Stenopterygiidae in southern France is also corroborated by SANDER \& BUCHER (1993), who described a large cf. Stenopterygius from the upper Toarcian (aalensis Zone) of the Aveyron area. ELMI \& RULLEAU (1991) mentioned the presence of a large ichthyosaur in the middle Toarcian (bifrons Zone) of the "Lafarge" quarries of the Belmont locality, near Lyon. MARTIN et al. are currently studying this specimen, which is possibly a Temnodontosaurus (pers. obs.). In 1994, amateurs discovered two very large ichthyosaurs in the Causses region, one at the base of the lower Toarcian "schistes cartons" (paltus Sub-zone, tenuicostatum Zone) in the Causse du Larzac locality, and one from the upper Toarcian marls (pseudoradiosa Sub-zone, pseudoradiosa Zone) of the Barjac locality. Both specimens can be referred to Temnodontosaurus, based on the presence of long femora with a distinctive very flattened distal end. The Barjac specimen also includes cranial and scapular material that confirms its identification as Temnodontosaurus: the scapula is straight, and the skull and mandibles are high (skull is $40 \mathrm{~cm}$ high at the basicranium), with a wide, massive postorbital region. A description of these specimens (currently held in the private collection of J. Sciau) is desirable, but beyond the scope of this paper.

Temnodontosaurus is regarded as the top predator of Early Jurassic seas, probably preying on large marine reptiles (MASSARE 1987; 1988; BÖTTCHER 1989; GODEFROIT 1996; MCGOWAN 1996). The presence of Temnodontosaurus thus completes the picture, every Toarcian genus described in other basins across Europe being found in southern France as well, with the exception of Hauffiopteryx, a very rare Stenopterygiidae recently named by MAISCH (2008) for the reception of some specimens previously referred to as Stenopterygius hauffianus.

\subsection{Palaeobiogeography of Toarcian ichthyosaurs}

\subsubsection{State of the art}

Since the revision of Liassic ichthyosaurs by MCGOWAN (1974a; 1974b; 1979), several authors compared the different marine reptile faunas from the Toarcian of Europe. MCGOWAN (1978) argued for a wide distribution of most taxa based on the numerous adaptations of ichthyosaurs to life in the open sea. However, MCGOWAN subsequently indirectly "created" an important endemism among Toarcian ichthyosaurs by recognizing no less than seven, then eight species for as single genus, Stenopterygius (MCGOWAN 1979; MCGOWAN \& MOTANI 2003). GODEFROIT (1994; 1996), who studied the ichthyosaur fauna from southern Belgium and Luxembourg, questioned MCGowAN's (1979) diagnoses and proposed three valid species for Stenopterygius, and added the Belgoluxembourg fauna to the England-Germany dichotomy. From a palaeobiogeographical point of view, the main result of his work was that most genera and species of Toarcian ichthyosaurs could be found in those three localities, while significant differences between these basins existed in terms of relative species abundance.

More recently, MAISCH \& ANSORGE (2004) and GROßMANN (2006; 2007) suggested the existence of a well-marked provincialism in Toarcian marine reptiles. Using GODEFROIT's (1994) analysis, MAISCH \& ANSORGE (2004) proposed three zones characterized by distinctive marine reptiles 
assemblages: an "English zone" accounting for the fauna of central and western England, a

"Subgermanic zone" accounting for the fauna of the northeastern border of the Paris Basin (Belgium, Luxembourg, northeastern France) and a "Germanic zone" accounting for all German discoveries. Considering that there were no differences in terms of palaeoecology between these zones, they proposed that only a geographical barrier, such as the London-Brabant massif, could explain such a pronounced endemism between Toarcian marine reptiles. Based on her study of Toarcian plesiosaurs, GROßMANN $(2006$; 2007) proposed a fourth marine reptile zone: southern France, for the genus Occitanosaurus discovered in the Causses region, near Millau, close to the locality where the two Temnodontosaurus specimens discussed earlier were discovered.

\begin{tabular}{|c|c|c|c|c|}
\cline { 2 - 5 } \multicolumn{1}{c|}{} & Germany & Belg-Lux & England & Southern France \\
\hline Stenopterygius & $\begin{array}{c}\text { quadriscissus } \\
\text { triscissus } \\
\text { uniter }\end{array}$ & $\begin{array}{c}\text { quadriscissus } \\
\text { triscissus } \\
\text { uniter }\end{array}$ & $\begin{array}{c}\text { quadriscissus } \\
\text { triscissus }\end{array}$ & $\begin{array}{c}\text { Thunnosauria } \\
\text { indet. aff. } \\
\text { Stenopterygiidae }\end{array}$ \\
\hline Suevoleviathan & $\begin{array}{c}\text { typicus } \\
\text { integer }\end{array}$ & typicus & typicus & $\mathrm{sp}$. \\
\hline Temnodontosaurus & trigonodon & & $\begin{array}{c}\text { crassimanus? } \\
\text { acutirostris? }\end{array}$ & $\mathrm{sp}$. \\
\hline Eurhinosaurus & longirostris & longirostris & longirostris & $\mathrm{sp}$. \\
\hline
\end{tabular}

Table 3: Faunal comparison between major lower to middle Toarcian ichthyosaur-bearing localities in Western Europe (MCGowan 1978; Lamaud 1979; WeIDMANN 1981; Benton \& TAYlor 1984; SANDER \& BUCHER 1993; Godefroit 1994; 1996; MAISCH 1998a; 1998b; 2001; 2008; pers. comm. 2010; MAISCH \& MATZKE 2000; MCGOWAN \& Motani 2003; MAISCH \& ANSORGE 2004).

\subsubsection{Palaeobiogeographical significance of southern France ichthyosaurs}

Despite its geographical remoteness from other well-known localities and its proximity to the Tethys, the ichthyosaur fauna from southern France closely resembles that of other basins in Europe (Table 3). The presence of Suevoleviathan in the Vocontian Basin is particularly interesting from a palaeobiogeographical point of view, because this rare genus was previously only known from six specimens from the lower Toarcian shales of the Holzmaden area, some $500 \mathrm{~km}$ north of the Vocontian Basin (fig. 9). This new discovery thus seriously questions the provincialism hypothesis proposed by MAISCH \& ANSORGE (2004). As discussed by LINGHAM-SOLIAR (2003), Mesozoic marine reptiles include animals with really different ecologies and swimming capabilities and cannot be considered as a single adaptive assemblage. As previously shown by GODEFROIT (1994), the present paper highlights the strong similarities between ichthyosaur faunas across Europe in terms of taxon occurrence at the generic level (Table 3). At the current state of our knowledge, it is difficult to assess the palaeobiogeography of Toarcian ichthyosaurs at the species level, because their validity is either doubtful, such as for T. crassimanus, or they have not yet been formally recognised in other localities: a revision of all species of the genera Stenopterygius and Hauffiopteryx has been done by MAISCH (2008), but mostly based on the German forms. Their presence in all other localities cannot be assessed without a complete re-study of the abundant European material, but MAISCH recognized both H. typicus and S. triscissus in Holzmaden, Ilminster, Whitby, and Belgoluxembourg. Consequently, a clear pattern of ubiquity at the generic level stands out from this dataset. On the contrary, a marked endemism in plesiosaurs, even at generic level, appears to be real (GODEFROIT 
1994; GROßMANN 2006; 2007; VINCENT \& SUAN 2009). Toarcian marine crocodiles also show some degree of provincialism (GODEFROIT 1994). It is thus important to consider each group of marine reptiles separately when discussing palaeobiogeography. The absence of the genus Suevoleviathan from the English and Belgoluxembourg localities could also be explained by collecting biases. Indeed, out of the 3000 specimens from Holzmaden area, only six have been referred to Suevoleviathan (MAISCH 1998b; 2001). Toarcian ichthyosaurs are much less abundant in the English and in the Belgoluxembourg localities, and we were probably very lucky to find a specimen of Suevoleviathan among the twelve ichthyosaurs in the collections of the RGHP. Furthermore, the last re-evaluation of the English Toarcian material was made more than 25 years ago (BENTON \& TAYLOR 1984). Most of the species discussed in their paper are taxonomically doubtful (e.g. Temnodontosaurus crassimanus) or their generic attribution must be revised. At the current state of our knowledge, provincialism in Toarcian ichthyosaurs cannot be demonstrated convincingly at the generic level.

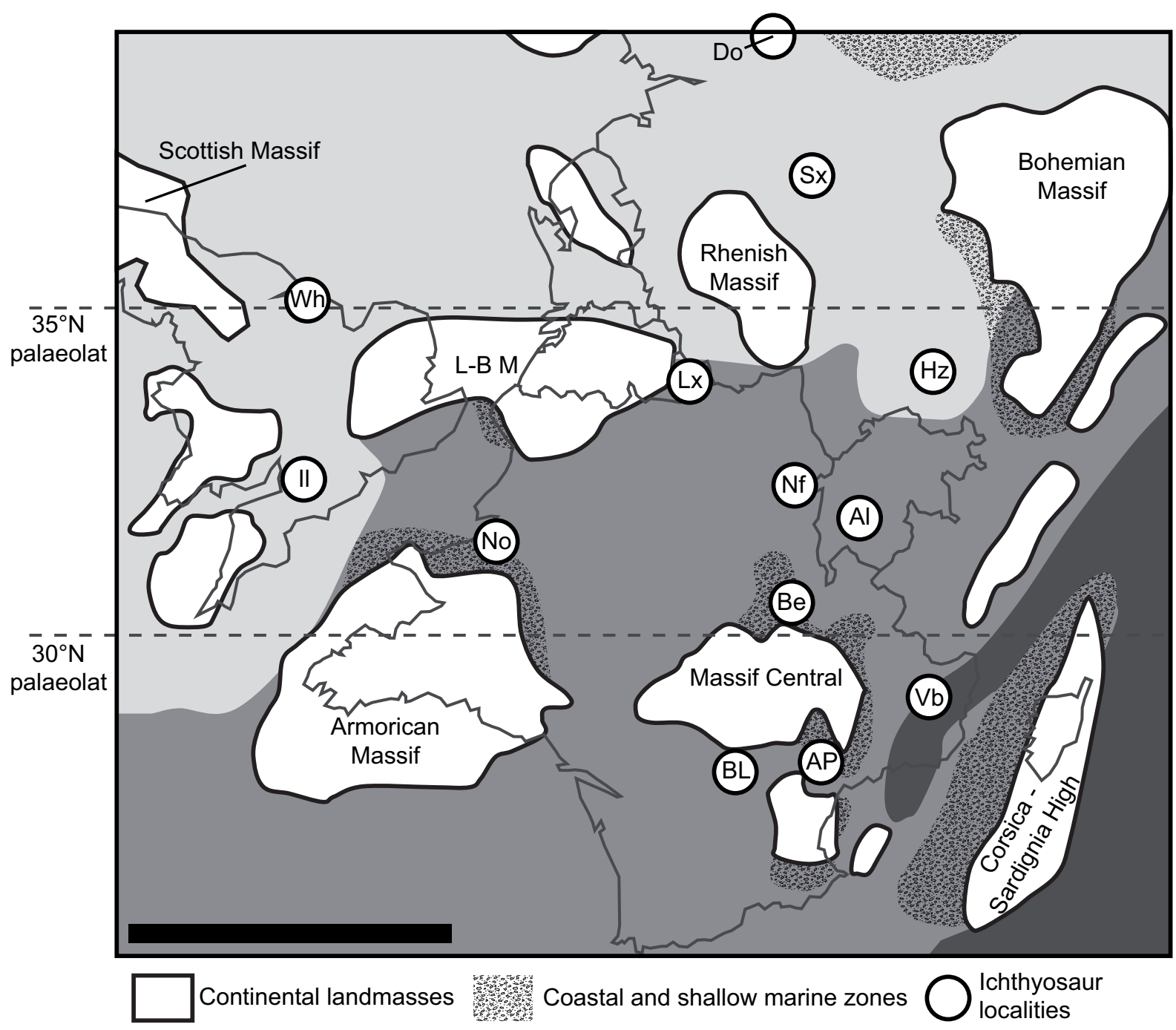

Temperate sea Subtropical waters

Tropical oceanic waters

Figure 9: Palaeobiogeography of Toarcian ichthyosaurs from Western Europe within their palaeoceanographical and palaeogeographical context. Al: Swiss Alps and Teysachaux (WEIDMANN 1981; MAISCH \& MATZKE 2000). AP: Aveyron and Pic Saint-Loup (LAMAud 1979; SANDER \& BUCHER 1993). Be: Belmont d'Azergues (ELMI \& RULlEAU 1991). BL: Barjac and Lozère regions (SANDER \& BUCHER 1993; MAZIN \& BARDET pers. comm. 2009; this work). Do: Dobbertin area (MAISCH \& ANSORGE 2004). Hz: Holzmaden area (MCGOwAN 1979; MAISCH \& MATZKE 2000; MCGOWAN \& MOTANi 2003). Il: Ilminster and Kingstorpe area (BENTON \& TAYLOR 
1984). Lx: Belgium and Luxembourg (GodEFroit 1994; 1996). Nf: Noirefontaine (MAISCH \& MATZKE 2000). No: Normandy, including Curcy (Huene 1922; Dechaseaux 1954; MaISCH \& MATZKE 2000). Sx: southern Saxony (MAISCH \& ANSORGE 2004). Vb: Vocontian Basin and Loube Massif (Aalenian) (ARNAUD et al. 1976; this work). Wh: Whitby area (MCGOWAN 1974a; 1974b; 1978; BENTON \& TAYLOR 1984; MCGOWAN \& MotANI 2003). Toarcian ichthyosaurs have also been found in Portugal and Spain (BARDET et al. 2008). (Palaeogeography and palaeoceanography from THIERRY \& BARRIER 2000; MAISCH \& ANSORgE 2004; ARIAS \& WhatLey 2005; Colombié \& STRASSER 2005; ARIAS 2007; GroßMANN 2007; LÉONIDE et al. 2007; MAILLIOT et al. 2009). Scale bar equals $500 \mathrm{~km}$.

Consequently, the only remaining discernible difference between the European basins in terms of ichthyosaur assemblages is the relative species abundance pointed out by GODEFROIT (1996). MAISCH \& ANSORGE's (2004) hypothesis of geographical barriers fails to explain the presence of the same taxa in the different basins. In fact, differences between ichthyosaur assemblages (including the possible absence of certain species in certain localities), could be readily explained by palaeoecology and preservation biases. Indeed, HEIMHOFFER et al. (2006) and HARDAS \& MUTTERLOSE (2007) showed that anoxic black marls or shales could form in different palaeoenvironments. Furthermore, the early Toarcian black shales record a worldwide event of anoxia (the Toarcian Oceanic Anoxic Event, TOAE) (MAILLIOT et al. 2009). This suggests that despite lithological similarities, these black shales were probably deposited in contrasting - but still confined - palaeoenvironments, closer or further from nearby islands of the archipelago, as already deduced by GODEFROIT $(1994 ; 1996)$ from palaeontological evidence. ARIAS \& WHATLEY (2005) and ARIAS (2007), who studied ostracods, demonstrated the existence of palaeoceanological differences in the European Epicontinental Sea, and distinguished a northern temperate sea, a median shallow subtropical sea and southern tropical oceanic waters (fig. 9), which varied in numerous parameters such as temperature, salinity and depth. The English ichthyosaur-bearing localities fall in the northern temperate sea, the southern German and Belgoluxembourg localities are close to the boundary between the temperate and subtropical sea, most French localities are within the subtropical sea, and the Vocontian Basin belongs to the oceanic tropical realm. Altogether, the places where anoxic shales deposited represent preservation "hot spots" where macrofauna, microfauna and palaeoenvironmental proxies were rather likely to be preserved, meaning that our knowledge of the complex ecosystem of the European archipelago is very punctual. We propose that the differences between well-known localities in terms of relative species abundance are due to palaeoenvironmental factors rather than geographical isolation. The excellent swimming capabilities of ichthyosaurs (MASSARE 1988; LINGHAM-SOLIAR \& PLODOWSKI 2007) and their ability to share food resources (MASSARE, 1987; 1997; GODEFROIT 1996) explains their presence in many localities. However, it is can be assumed that each taxon had ecological preferences, explaining both the relative species abundance discrepancies and the possible absence of certain taxa in certain localities, particularly for members of the Stenopterygiidae. Eurhinosaurus had apparently an even, Europe-wide distribution.

\section{Conclusions}

The ichthyosaur taxa Suevoleviathan sp.; Eurhinosaurus sp. and Thunnosauria indet. aff. Stenopterygiidae are described from the Toarcian of the Vocontian Basin, at the northwestern border of the Tethys realm. It is the first time that the genus Suevoleviathan is reported outside the southern German basin. Despite its geographical remoteness, the southern France assemblage closely resembles that of other localities across Europe, suggesting a wide distribution for most ichthyosaur genera, contrasting with Toarcian plesiosaurs, characterized by a high degree of endemism. 


\section{Acknowledgements}

V.F. is supported by a FNRS grant (Aspirant du F.R.S. - FNRS). J. Sciau and the staff of the RGHP receive our sincere acknowledgements for providing access to specimens. Authors sincerely thank Dr. Michael Maisch (University Tübingen) and Prof. Martin Sander (University Bonn) for their very constructive comments on the manuscript.

\section{REFERENCES}

ARIAS, C. (2007): Pliensbachian-Toarcian ostracod biogeography in NW Europe: Evidence for water mass structure evolution.-Palaeogeography Palaeoclimatology Palaeoecology, 251: 398-421. ARIAS, C. \& WHATLEY, R. (2005): Palaeozoogeography of Western European Lower Jurassic (Pliensbachian and Toarcian) Ostracoda.-Geobios, 38: 697-724.

ARnaud, M., Monleau, C. \& WenZ, S. (1976): Découverte de restes d'ichthyosaure dans l'Aalénien du Massif de la Loube (Var).-Bulletin du Musée d'Histoire Naturelle de Marseille, 36: 3pp.

BARDET, N. (1992): Stratigraphic evidence for the extinction of the ichthyosaurs.-Terra Nova, 4: 649656.

BARDET, N. (1994): Extinction events among Mesozoic marine reptiles.-Historical Biology, 7: 313324.

BARDET, N. \& FERNÁNDEZ, M. (2000): A new ichthyosaur from the Upper Jurassic lithographic limestones of Bavaria.-Journal of Paleontology, 74: 503-511.

BARdeT, N., PEREDA Suberbiola, X. \& Ruiz OMEÑACA, J. I. (2008): Mesozoic marine reptiles from the Iberian Peninsula.-Geo-Temas, 10: 1245-1248.

BENTON, M. J. \& TAYLOR, M. A. (1984): Marine reptiles from the Upper Lias (Lower Toarcian, Lower Jurassic) of the Yorkshire coast.-Proceedings of the Yorkshire Geological Society, 44: 399429.

BÖTTCHER, V. R. (1989): Über die Nahrung eines Leptopterygius (Ichthyosauria, Reptilia) aus dem süddeutschen Posidonienschiefer (Unterer Jura) mit Bemerkungen über den Magen der

Ichthyosaurier--Stuttgarder Beiträge zur Naturkunde Serie B (Geologie und paläontologie), 155: 1-19. BuchHOLTZ, E. A. (2001): Swimming styles in Jurassic ichthyosaurs.-Journal of Vertebrate

Paleontology, 21: 61-73.

COlOMBIÉ, C. \& STRASSER, A. (2005): Facies, cycles and controls on the evolution of a keep-up carbonate platform (Kimmeridgian, Swiss Jura).-Sedimentology, 52: 1207-1227.

DANELIAN, T., LAHSINI, S. \& DE RAFELIS, M. (2006): Upper Jurassic Radiolaria from the Vocontian Basin of SE France. Radiolaria and siliceous plankton through time.-Eclogae geologicae Helvetiae, 99: 35-47.

De Graciansky, P.-C., Dardeau, G., Dumont, T., Jacquin, T., Marchand, D., Mouterde, R. \& VAIL, P. R. (1993): Depositional sequence cycles, transgressive-regressive facies cycles, and extensional tectonics : example from the southern Subalpine Jurassic basin, France.-Bulletin de la Société géologique de France, 164: 709-718.

DeChaSEAUX, C. (1954): L'arrière-crâne d'un ichthyosaurien du Lias.-Annales de Paléontologie, 40: 67-77.

ELMI, S. \& RULLEAU, L. (1991): Le Toarcien des carrières Lafarge (Bas-Beaujolais, France): cadre biostratigraphique de référence pour la région lyonnaise.-Geobios, 24: 315-331.

Floquet, M., Cecca, F., Mestre, M., Macchioni, F., Guiomar, M., BAudin, F., Durlet, C. \& ALMERAS, Y. (2003): Mass mortality or exceptional fossilization? The case of the early and middle 
Toarcian fossiliferous beds from the Digne-Les-Bains area (southeastern France).-Bulletin de la Société géologique de France, 174: 159-176.

Floquet, M., GuiOMAR, M. \& DOMMERGues, J.-L. (2007): Trois gisements fossilifères phares de la Réserve géologique de Haute-Provence, field trip guide.-Congrès de L'Association paléontologique française, 3-5 mai 2007, Digne-les-bains (unpubl.). 42.

GODEFROIT, P. (1994): Les reptiles marins du Toarcien (Jurassique inférieur) belgo-luxembourgeois.Mémoires pour servir à l'Explication des Cartes Géologiques et Minières de la Belgique, 39: 98pp. GODEFROIT, P. (1996): Biodiversité des reptiles marins du Jurassique inférieur belgoluxembourgeois.-Bulletin de la Société belge de Géologie, 104: 67-76.

GROßMANN, F. (2006): Taxonomy, phylogeny and palaeoecology of the plesiosauroids

(Sauropterygia, Reptilia) from the Posidonia shale (Toarcian, Lower Jurassic) of Holzmaden, South West Germany-Geowissenschaftlichen Fakultät, Ph.D. Thesis. Eberhard-Karls-Universität Tübingen, (unpubl.). 127pp.

GROßMANN, F. (2007): The taxonomic and phylogenetic position of the Plesiosauroidea from the Lower Jurassic Posidonia shale of south-west Germany.-Palaeontology, 50: 545-564.

HaCCARD, D., BEAUdoin, B., GigOt, P. \& JordA, M. (1989): La Javie.-Carte Géologique de France à $1 / 50000$. BRGM (Ed.).

HARDAS, P. \& MUTTERLOSE, J. (2007): Calcareous nannofossil assemblages of Oceanic Anoxic Event 2 in the equatorial Atlantic: Evidence of an eutrophication event.-Marine Micropaleontology, 66: 5269.

Heimhofer, U., Hochuli, P. A., Herrle, J. O. \& Weissert, H. (2006): Contrasting origins of Early Cretaceous black shales in the Vocontian Basin : Evidence from palynological and calcareous nannofossil records.-Palaeogeography Palaeoclimatology Palaeoecology, 235: 93-109.

HuENE, F. V. (1922): Die Ichthyosaurier des Lias und ihre Zusammenhänge.-Monographien zur Geologie und Paläontologie, 1. 114pp; Berlin (Verlag von Gebrüder Borntraeger).

HuENE, F. V. (1926): Neue Ichthyosaurierfunde aus dem Schwäbischen Lias.-Neues Jahrbuch für Mineralogie, Geologie, und Paläontologie, B, 55: 66-86.

HuENE, F. V. (1939): Ein ganzes Ichthyosaurier-Skelett aus den west-schiezerischen Voralpen.Mitteilungen der Naturforschenden Gesellschaft Bern, 1939: 14pp.

JOHNSON, R. (1977): Size independent criteria for estimating relative age and the relationship among growth parameters in a group of fossil reptiles (Reptilia: Ichthyosauria).-Canadian Journal of Earth Sciences, 14: 1916-1924.

KEAR, B. P. (2005): Cranial morphology of Platypterygius longmani Wade, 1990 (Reptilia:

Ichthyosauria) from the Lower Cretaceous of Australia.-Zoological Journal of the Linnean Society, 145: 583-622.

LAMAUD, P. (1979): Les Ichthyosaures et la mer toarcienne du Pic Saint-Loup.-Minéraux et fossiles. Le guide du collectionneur, 58: 42-49.

LÉONIDE, P., FLOQUET, M. \& VILLIER, L. (2007): Interaction of tectonics, eustasy, climate and carbonate production on the sedimentary evolution of an early/middle Jurassic extensional basin (Southern Provence Sub-basin, SE France).-Basin Research, 19: 125-152.

LINGHAM-SOLIAR, T. (2003): Extinction of ichthyosaurs: a catastrophic or evolutionary paradigm?Neues Jahrbuch für Geologie und Paläontologie. Abhandlungen., 228: 421-452.

LingHAM-SOliAR, T. \& PLODOWSKI, G. (2007): Taphonomic evidence for high-speed adapted fins in thunniform ichthyosaurs.-Naturwissenschaften, 94: 65-70.

LYDEKKER, R. (1888): Note on the classification of the Ichthyopterygia with a notice of two new species.-Geological Magazine third series, 5: 309-314.

Mailliot, S., Mattioli, E., Bartolini, A., Baudin, F., Pittet, B. \& GueX, J. (2009): Late

Pliensbachian-early Toarcian (Early Jurassic) environmental changes in an epicontinental basin of 
NW Europe (Causses area, central France): A micropaleontological and geochemical approach.Palaeogeography Palaeoclimatology Palaeoecology, 273: 346-364.

MAISCH, M. W. (1997): The cranial osteology of Ichthyosaurus intermedius Conybeare, 1822 from the Lias of Great Britain.-Stuttgarter Beiträge zur Naturkunde: Serie B Geologie und Paläontologie, 258: 27pp.

MAISCH, M. W. (1998a): Kurze Übersicht der Ichthyosaurier des Posidonienschiefers mit Bemerkungen zur Taxionomie der Stenopterygiidae und Temnodontosauridae.-Neues Jahrbuch für Geologie und Paläontologie. Abhandlungen, 209: 401-431.

MAISCH, M. W. (1998b): A new ichthyosaur genus from the Posidonia Shale (Lower Toarcian, Jurassic) of Holzmaden, SW-Germany with comments on the phylogeny of post-Triassic ichthyosaurs.-Neues Jahrbuch für Geologie und Paläontologie. Abhandlungen, 209: 47-78. MAISCH, M. W. (2001): Neue Exemplare der seltenen Ichthyosauriergattung Suevoleviathan Maisch 1998 aus dem Unteren Jura von Südwestdeutschland.-Geologica et Palaeontologica, 35: 145-160. MAISCH, M. W. (2008): Revision der Gattung Stenopterygius Jaekel, 1904 emend. von Huene, 1922 (Reptilia: Ichthyosauria) aus dem unteren Jura Westeuropas.-Palaeodiversity, 1: 227-271.

MAISCH, M. W. \& ANSORGE, J. (2004): The Liassic ichthyosaur Stenopterygius cf. S. quadrissicus from the lower Toarcian of Dobbertin (NE Germany) and some considerations on lower Toarcian marine reptile palaeobiogeography.-Paläontologische Zeitschrift, 78: 161-171.

MAISCH, M. W. \& MATZKE, A. T. (2000): The Ichthyosauria.-Stuttgarter Beiträge zur Naturkunde: Serie B Geologie und Paläontologie, 298: 159pp.

MAISCH, M. W. \& REISDORF, A. G. (2006): Evidence for the longest stratigraphic range of a postTriassic Ichthyosaur: a Leptonectes tenuirostris from the Pliensbachian (Lower Jurassic) of Switzerland.-Geobios, 39: 491-505.

MASSARE, J. A. (1987): Tooth morphology and prey preference of Mesozoic marine reptiles.-Journal of Vertebrate Paleontology, 7: 121-137.

MASSARE, J. A. (1988): Swimming capabilities of Mesozoic marine reptiles: implications for the methods of predation.-Palaeobiology, 14: 187-205.

MASSARE, J. A. (1997): Faunas, behavior, and evolution.-In: CAllaWAY, J. M. \& NiCHOLLS, E. L. (Eds.): Ancient Marine Reptiles, 401-421; San Diego, California (Academic Press).

MAZIN, J.-M. (1988): Le crâne d'Ichthyosaurus tenuirostris Conybeare, 1822 (Toarcien, La Caîne, Normandie, France).-Bulletin de la Société linéenne de Normandie, 112-113: 121-132.

MCGOWAN, C. (1974a): A revision of the latipinnate ichthyosaurs of the Lower Jurassic of England (Reptilia, Ichthyosauria).-Life Science Contributions, Royal Ontario Museum, 100: 1-30.

MCGOWAN, C. (1974b): A revision of the longipinnate ichthyosaurs of the Lower Jurassic of England, with description of the new species (Reptilia, Ichthyosauria).-Life Science Contributions, Royal Ontario Museum, 97: 1-37.

MCGOWAN, C. (1976): The description and phenetic relationships of a new ichthyosaur genus from the Upper Jurassic of England.-Canadian Journal of Earth Sciences, 13: 668-683.

MCGOWAN, C. (1978): Further evidence for the wide geographical distribution of ichthyosaur taxa (Reptilia, Ichthyosauria).--Journal of Paleontology, 52: 1155-1162.

MCGOWAN, C. (1979): A revision of the Lower Jurassic ichthyosaurs of Germany with descriptions of two new species.-Palaeontographica. Abteilung A. Paläozoologie, Stratigraphie, 166: 93-135.

MCGOWAN, C. (1986): A putative ancestor for the swordfish-like ichthyosaur Eurhinosaurus.-Nature, 322: 454-456.

MCGOWAN, C. (1989a): Computed tomography reveals further details of Excalibosaurus, a putative ancestor for the swordfish-like ichthyosaur Eurhinosaurus.-Journal of Vertebrate Paleontology, 9: 269-281. 
MCGowAN, C. (1989b): Leptopterygius tenuirostris and other long-snouted ichthyosaurs from the English Lower Lias.-Palaeontology, 32: 409-427.

MCGowan, C. (1991): Dinosaurs, Spitfires, \& Sea Dragons.-365pp; (Harvard University Press).

MCGOWAN, C. (1994a): The taxonomic status of the Upper Liassic ichthyosaur Eurhinosaurus

longirostris.-Palaeontology, 37: 747-753.

MCGowan, C. (1994b): Temnodontosaurus risor is a juvenile of T. platyodon (Reptilia:

Ichthyosauria).--Journal of Vertebrate Paleontology, 14: 472-479.

MCGOWAN, C. (1996): Giant ichthyosaurs of the Early Jurassic.-Canadian Journal of Earth Sciences, 33: 1011-1021.

MCGOWAN, C. (2003): A new specimen of Excalibosaurus from the English Lower Jurassic.--Journal of Vertebrate Paleontology, 23: 950-956.

MCGowan, C. \& MiLneR, A. C. (1999): A new Pliensbachian ichthyosaur from Dorset, England.-

Palaeontology, 42: 761-768.

McGowan, C. \& Motani, R. (2003): Handbook of Paleoherpetology. Part 8 Ichthyopterygia. -8.

$175 \mathrm{pp}$; München (Verlag Dr. Friedrich Pfeil).

MOTANI, R. (1999): Phylogeny of the Ichthyopterygia.-Journal of Vertebrate Paleontology, 19: 473496.

PhARISAT, A. (1993): L'ichthyosaure de la base des schistes-cartons du Toarcien inférieur de Noirefontaine (Doubs).-Société d'Histoire Naturelle du Pays de Montbéliard, 1993: 193-198.

PhARISAT, A., CONTINI, D. \& FrIKERT, J.-C. (1993): Early Jurassic (Lower Toarcian) "ichthyosaurs" from France-Comté, France.-Revue de Paléobiologie, volume spécial, 7: 189-198.

RIESS, J. (1986): Fortbewegungsweise, Schimmbiophysik und Phylogenie der Ichthyosaurier.Palaeontographica. Abteilung A. Paläozoologie, Stratigraphie, 192: 93-155.

RÖHL, H.-J., SCHMID-RÖHL, A., OSCHMANN, W., FRIMMEL, A. \& SCHWARK, L. (2001): The Posidonia Shale (Lower Toarcian) of SW Germany: an oxygen-depleted ecosystem controlled by sea level and palaeoclimate.-Palaeogeography, Palaeoclimatology, Palaeoecology, 169: 273-299.

SANDER, P. M. (2000): Ichthyosauria: their diversity, distribution, and phylogeny.-Paläontologische Zeitschrift, 74: 1-35.

SANDER, P. M. \& BUCHER, H. (1993): An ichthyosaur from the uppermost Toarcian of southern France.-Neues Jahrbuch für Geologie und Paläontologie. Monatshefte, 1993: 631-640.

SCHMID-RÖHL, A. \& RÖHL, H.-J. (2003): Overgrowth on ammonite conchs: enviromental implications for the Lower Toarcian Posidonia shale.-Palaeontology, 46: 339-352.

TAYLOR, P. D. \& WILSON, M. A. (2003): Palaeoecology and evolution of marine hard substrate communities.-Earth-Science Reviews, 62: 1-103.

THIERRY, J. \& BARRIER, E. (2000): Map 8 Middle Toarcian.-In: DERCOURT, J., GAETANI, M., VRIElynck, B., BARrier, E., BiJu-Duval, B., Brunet, M. F., CAdet, J. P., Crasquin, S. \& SANDUleSCU, M. (Eds.): Atlas Peri-Tethys, Palaeogeographical maps, Paris (CCGM/CGMW). VINCENT, P. \& SUAN, G. (2009): Diversity and paleogeographic distribution of Early Jurassic plesiosaurs.-Tribute to Charles Darwin and Bernissart Iguanodons: new perspectives on Vertebrate Evolution and Early Cretaceous Ecosystems, Brussels (unpubl.). 97.

WeIDMAnN, M. (1981): Un Ichthyosaure dans le Lias supérieur des Préalpes médianes vaudoises.Bulletin de la Société vaudoise des Sciences naturelles, 75: 165-170.

WILPSHAAR, M., LEEREVELD, H. \& VISSCHER, H. (1997): Early Cretaceous sedimentary and tectonic development of the Dauphinois Basin (SE France).-Cretaceous Research, 18: 457-468.

\section{Addresses of the authors}


VALENTIN FISCHER. Palaeontology Department, Royal Belgian Institute of Natural Sciences, Rue Vautier 29, 1000 Brussels, Belgium and Département de Géologie, Centre de Geosciences, Université de Liège, B-18, Allée du 6-août, Liège, Belgium;

E-mail: v.fischer@ulg.ac.be

MyETTE GuiOMAR. Réserve naturelle géologique de Haute Provence, Montée Bernard

Dellacasagrande 10, 04005 Digne-les-Bains, France;

E-mail: m.guiomar@,resgeol04.org

PASCAL GODEFROIT. Palaeontology Department, Royal Belgian Institute of Natural Sciences, Rue Vautier 29, 1000 Brussels, Belgium;

E-mail: Pascal.Godefroit@naturalsciences.be 